\title{
Germination of Macroptilium lathyroides seeds as a function of the presence of salts on the substrate
}

Weeds are species evolutionarily adapted to development in areas of disorders caused by man or not. Adoption of practices to control and integrated weed management, it is essential the knowledge related to germination and environmental factors that interfere with seed germination processes. In this context, the present work aimed to evaluate the behavior of Macroptilium lathyroides seeds in response to different levels of osmotic potential induced $\mathrm{NaCl}$ and $\mathrm{CaCl} 2$ solutions. The experiment has been organized in a completely randomized design in a factorial $2 \times 6$, consisting of two salts in concentrations 6 with 4 repetitions. The seeds were kept in on moistened gerboxes germibox roles with $\mathrm{NaCl}$ and $\mathrm{CaCl} 2$ solutions at the potentials of $0.0 ;-0.2 ;-0.4 ;-0.6 ;-0.8$ and $-1.0 \mathrm{MPa}$. Daily reviews by germination, IVG and end ten days were determined shoot length, root length and plantlet dry weight were performed. The results demonstrated that salt stress induced by $\mathrm{NaCl}$ and $\mathrm{CaCl} 2$ provokes a gradual reduction in germination of $\mathrm{M}$. lathyroides there is no tolerance limit. The $\mathrm{NaCl}$ The salt was more critical root development and of the seedlings dry weight.

Keywords: Salt Stress; Weeds; Osmotic Potential.

\section{Germinação de sementes de Macroptilium lathyroides em função da presença de sais no substrato}

\begin{abstract}
As plantas daninhas são espécies adaptadas evolutivamente para o desenvolvimento em áreas de distúrbio, provocadas ou não pelo homem. Para adoção de práticas de controle e manejo integrado de plantas daninhas, torna-se imprescindivel o conhecimento de aspectos relacionados à germinação e dos fatores ambientais que interferem nos processos germinativos das sementes. Nesse contexto, o presente trabalho teve como objetivo avaliar comportamento de sementes de Macroptilium lathyroides sob efeito de diferentes níveis de potenciais osmóticos induzidos por soluções de $\mathrm{NaCl}$ e $\mathrm{CaCl}$. $\mathrm{O}$ experimento foi organizado em delineamento inteiramente casualizado, no esquema fatorial $2 \times 6$, constituídos por 2 sais em 6 concentrações, com 4 repetições. As sementes foram mantidas em caixas gerbox sobre papéis umedecidos com soluções de $\mathrm{NaCl}$ e $\mathrm{CaCl} 2$, nos potenciais hídricos de 0,$0 ;-0,2 ;-0,4 ;-0,6 ;-0,8$ e $-1,0 \mathrm{MPa}$. Foram realizadas avaliações diárias de germinação, IVG e no final de dez dias, foram determinados comprimento da parte aérea, comprimento radicular e massa seca de plântula. Os resultados demonstraram que o estresse salino induzido pela solução de $\mathrm{NaCl}$ e $\mathrm{CaCl} 2$ provocam redução gradativa na germinação das sementes de $\mathrm{M}$. lathyroides, não havendo limite de tolerância. $\mathrm{O}$ sal $\mathrm{NaCl}$ foi mais crítico no desenvolvimento radicular e peso seco das plântulas.
\end{abstract}

Palavras-chave: Estresse Salino; Plantas Daninhas; Potencial Osmótico.

Marcia de Souza Almeida da Silva (iD) Universidade do Estado de Mato Grosso, Brasil http://lattes.cnpq.br/8137422547836376 http://orcid.org/0000-0002-4350-0633 marcya biologia@hotmail.com

\section{Oscar Mitsuo Yamashita (D)}

Universidade do Estado de Mato Grosso, Brasil http://lattes.cnpq.br/1761470950121024 http://orcid.org/0000-0001-6715-626X yama@unemat.br

Ana Aparecida Bandini Rossi (ii) Universidade do Estado de Mato Grosso, Brasil http://lattes.cnpq.br/2734433144153549 http://orcid.org/0000-0002-8318-5375 anabanrossi@gmail.com

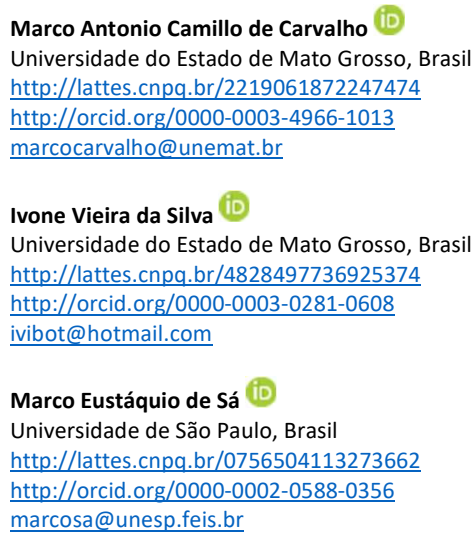

Germani Concenço (D)

Universidade Federal de Viçosa, Brasil http://lattes.cnpq.br/5235553101072050 http://orcid.org/0000-0003-2203-8766 germani.concenco@embrapa.br

\section{Rivanildo Dallacort (iD}

Universidade do Estado de Mato Grosso, Brasil http://lattes.cnpq.br/1292986021348016 http://orcid.org/0000-0002-7634-8973 rivanildo@unemat.br

\section{Referencing this:}

SILVA, M. S. A.; YAMASHITA, O. M.; ROSSI, A. A. B.; CARVALHO, M. A. C.; SILVA, I. V.; SÁ, M. E.; CONCENÇO, G.; DALLACORT, R.. Germination of Macroptilium lathyroides seeds as a function of the presence of salts on the substrate. Revista Ibero Americana de Ciências Ambientais, v.11, n.2, p.62-68, 2020. DOI: http://doi.org/10.6008/CBPC2179-6858.2020.002.0007 


\section{INTRODUCTION}

Weeds are species adapted evolutionarily for development in disturbed areas, caused or not by man. These plants interfere with agroforestry activities, reducing agricultural efficiency and causing economic losses (CONCENÇO et al., 2014). As cultural practices change, weeds that are less adapted to these practices tend to decrease or disappear, while the more adapted weeds, which were normally less frequent in the beginning, may start to dominate the area (GOMES JÚNIOR et al., 2008)..

Among the weeds with this greater rusticity, some have caused concern, given the ability to interfere in the production of grains under no-tillage systems. One of these plants is Macroptilium lathyroides, also known as pigeon beans, which has been reported as a species of high infestation power in soybean and cotton crops in the state of Mato Grosso do Sul, Brazil (CONCENÇO et al., 2012).

In order to adopt practices of control and integrated management of weeds, it is essential to know aspects related to germination and environmental factors that interfere in the germination processes of seeds (Thomas et al., 2006). Among these, soil salinity is one of the factors of greatest stress for plants and can negatively affect important physiological processes (YAMASHITA et al., 2011). One of the methods frequently used to determine the tolerance of plants to salt stress is to observe the germination capacity of the seeds under salinity conditions in the substrate (TAIZ et al., 2006).

Thus, species sensitive to environments with a high concentration of salts in the substrate, during the initial germination processes, are subject to conditions that limit their development and the chances of survival of these plants (MOUD et al., 2008; LIMA et al., 2009). The water is osmotically retained in the saline solution, so that the increase in the concentration of salts makes it less and less available to plants and may also facilitate the entry of toxic ions into the seeds (MEDEIROS et al., 2009).

Knowledge about how stress influences seed germination is extremely important for ecophysiology, as it assists in the assessment of tolerance limits and adaptive capacity of species (LARCHER, 2006; PELEGRINI et al., 2013). In addition, the period of germination and establishment of seedlings of weeds is particularly important, due to the competitive capacity with the plant of commercial interest. In this context, the present study aimed to evaluate the behavior of $M$. lathyroides seeds under the effect of different levels of osmotic potentials induced by $\mathrm{NaCl}$ and $\mathrm{CaCl}_{2}$ solutions.

\section{MATERIALS AND METHODS}

M. lathyroides seeds were collected from soybean crops infested by this plant, in the region of Batayporã (MS). Subsequently, they were reproduced in a protected environment, aiming at the production and collection of seeds for further studies. The reproduced seeds were placed to dry in a dry, shaded place and then packed in paper bags and stored in a refrigeration chamber at a temperature of $10 \cong \mathrm{C}( \pm 2 \circ \mathrm{C})$ until the moment of the installation of the experiment. The method used to overcome seed dormancy was immersion in sulfuric acid for 20 minutes followed by washing in running water for 5 minutes (ALMEIDA et al., 1979). 
To simulate salt stress and to determine the maximum limit of tolerance to salts, the seeds were submitted to different treatments that consisted of the combination of six osmotic potentials $(0.0 ;-0.2 ;-0.4$; $-0.6 ;-0.8$ and $-1.0 \mathrm{MPa}$ ) induced by $\mathrm{NaCl}$ and $\mathrm{CaCl}_{2}$ solutions, organized in a completely randomized design, configuring a $2 \times 6$ factorial scheme, with two salts and six potentials, with four replications of 25 seeds. Saline solutions were prepared using the Van't Hoff equation cited by Yamashita et al. (2011). The isotonic coefficients for the saline agents $\mathrm{NaCl}$ and $\mathrm{CaCl}_{2}$ are 1.8 and 2.4, respectively. The electrical conductivity was $3.09,5.20,9.55,12.80,14.68\left(\mathrm{dSm}^{-1}\right.$ at $\left.25 \stackrel{\circ}{\circ}\right)$ in $\mathrm{NaCl}$ and $4.71,8.15,9.44,12.41,13.79\left(\mathrm{dSm}^{-1}\right.$ at $\left.25 \stackrel{\circ}{ } \mathrm{C}\right)$ in $\mathrm{CaCl}_{2}$, determined by a portable conductivity meter (CD-880 Instrutherm).

Acrylic boxes of the gerbox type $(11.0 \times 11.0 \times 3.5 \mathrm{~cm})$ were used as experimental units, subjected to previous aseptic treatment by cleaning with sodium hypochlorite (10\%), two hours before the experiments were set up. The seeds were placed to germinate in the acrylic boxes on two sheets of germitest paper (previously autoclaved), moistened with each of the salt concentrations in the proportion of 2.5 times the mass of the dry substrate [13], and later placed in germination chambers type BOD with $12 \mathrm{~h}$ light regime, by means of a set of four white lamps, which provide approximately $0.012 \mathrm{~W} \mathrm{~m}^{-2} \mathrm{~nm}^{-1}$, under constant temperature of $25^{\circ} \mathrm{C}$.

The following variables were evaluated: germination percentage, germination speed index, root length, shoot length and seedling dry mass on the tenth day, at the end of the evaluation period, as described below:

Germination percentage - It was considered as a criterion for germination the emission of primary root with a length equal to $2 \mathrm{~mm}$ and the number of germinated seeds was counted daily, for a period of ten days [13]. The calculations were performed according to the formula below:

$$
G(\%)=\left(\frac{N}{A}\right) x 100
$$

where: $\mathrm{N}=$ Number of germinated seeds $A=$ total number of seeds.

Germination speed index (IVG) - It was carried out in conjunction with the germination test, the IVG for each subsample was obtained according to the formula presented by Maguire (1962), below:

$$
I V G=\frac{N_{1}}{D_{1}}+\frac{N_{2}}{D_{2}}+\ldots+\frac{N_{n}}{D_{n}}
$$

where: $\mathrm{N} 1: \mathrm{n}=$ number of seedlings germinated on day $1, \ldots ., \mathrm{n}$; D1: $n=$ days for germination to occur.

Length of aerial part and root of seedlings - They were evaluated together with the germination test, using all the normal seedlings of each repetition, measured with a millimeter-graded ruler. The lengths of the aerial part and root of the seedlings, for each sample, were calculated by dividing the total measurements by the number of seedlings evaluated, obtaining average values.

Seedling dry mass - Defined as the average mass, expressed in grams, corresponding to the mass of each seedling by repetition, using a drying oven with air circulation, set at $65 \pm 3 \stackrel{\circ}{\circ}$ to constant weight, weighing on a scale with precision of $0.001 \mathrm{~g}$. All results were subjected to analysis of variance and the means 
compared by Tukey's test at 5\% probability, with the aid of the Sisvar statistical program (FERREIRA, 2014).

\section{RESULTS AND DISCUSSION}

As for the variables studied in the germination of $M$. lathyroides seeds submitted to salt stress, it was observed that there was a difference for the salts factor only for root length and dry mass. The potential factor presented a significant difference for all variables. There was an interaction between factors (potential * salts) only for aerial part, root and seedling dry mass (Table 1 ).

Table 1: Average square of the variables evaluated in the germination and development of Macroptilium lathyroides submitted to different salts and potentials.

\begin{tabular}{|l|l|l|l|l|l|}
\hline Factors & Germination (\%) & IVG (\%) & Aerial part & Root lenght & Dry mass \\
\hline Salt (S) & $90.04 \mathrm{~ns}$ & $5.64 \mathrm{~ns}$ & $20.502 \mathrm{~ns}$ & $2066.662^{*}$ & $7.5000^{*}$ \\
\hline Potential (P) & $610.677^{*}$ & $38.16^{*}$ & $3543.245^{*}$ & $12603.1606^{*}$ & $0.000015^{*}$ \\
\hline S*P & $41.30 \mathrm{~ns}$ & $2.59 \mathrm{~ns}$ & $92.510^{*}$ & $320.001^{*}$ & $5.0400^{*}$ \\
\hline Error & 25.98 & 1.62 & 9.21 & 74.53 & 1.31 \\
\hline C.V. (\%) & 19.96 & 19.95 & 11.58 & 21.96 & 15.39 \\
\hline
\end{tabular}

ns: not significant by the $\mathrm{F}$ test; ${ }^{*}$ : significant by the $\mathrm{F}$ test.

The data obtained in the germination test indicate that $M$. lathyroides seeds showed a significant difference for germination percentage and germination speed index (Table 1), with this behavior being shown in Figures 1 and 2 . It is observed that from the potential osmotic of $-0.4 \mathrm{MPa}$, the deleterious effects of excess salt caused significant reductions in germination and IVG, reaching a drop of $23.65 \%$ and $23.76 \%$, respectively, when compared to the control treatment. Based on these results, it can be said that the increase in $\mathrm{NaCl}$ and $\mathrm{CaCl}_{2}$ concentrations gradually impaired the germination process of seeds of this species, since, in none of the evaluated osmotic potentials, there was a complete reduction for these variables.

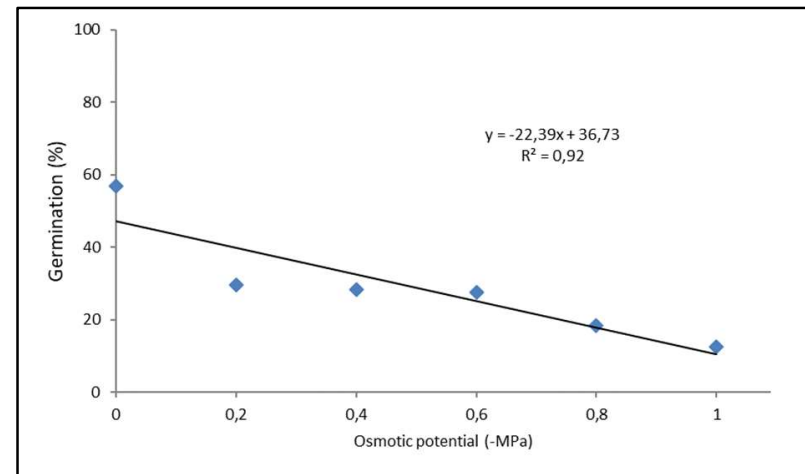

Figure 1: Germination of seeds (\%) of Macroptilium lathyroides submitted to osmotic potentials caused by salts.

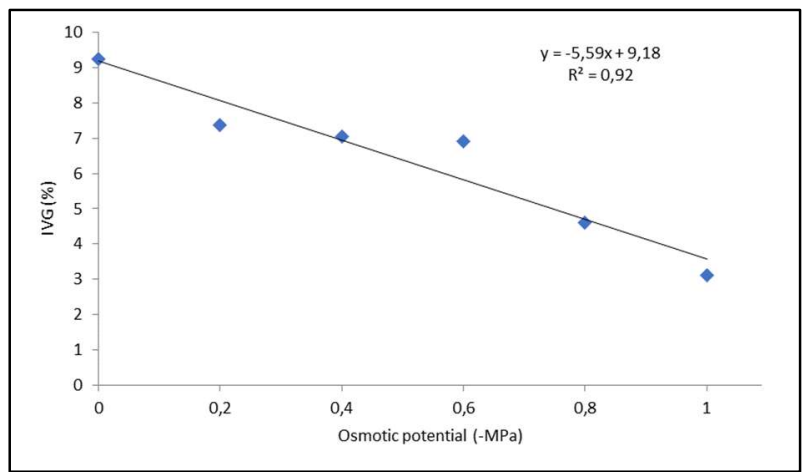

Figure 2: Germination speed index (IVG) of Macroptilium lathyroides seeds submitted to osmotic potentials caused by salts.

Salinity can compromise germination not only due to the toxic effect of the salts, but also hampering the absorption of water by the seeds due to the physiological drought produced, because with the increase in the concentration of salts there is a decrease in water potential, affecting the water absorption kinetics by the seeds (TORRES, 2007).

In a study with seeds of Raphanus raphanistrum and Senna obtusifolia, Pereira et al. (2014) observed a reduction in germination from the $-0.2 \mathrm{MPa}$ potential, with the minimum germinability limit of $-0.8 \mathrm{MPa}$ $\mathrm{NaCl}$. Similar results were also found by Martins et al. (2011) with seeds of Melaleuca quinquenervia. While 
for Emilia sonchifolia these values were -0.6 MPa (YAMASHITA et al., 2009).

The intensity of the germinative response to salt stress is variable between seeds of different species, and can also be observed in species of the same genus as verified by Pereira et al. (2012), in which in the potential -0.8 MPa of $\mathrm{NaCl}$, there was total inhibition of germination in Urochloa decumbens seeds, while for U. ruziziensis, in this same potential, $8 \%$ germination was observed.

In contrast, in $M$. lathyroides, values below $50 \%$ of the percentage observed in the control were obtained only from the potential - $0.8 \mathrm{MPa}$. The species showed germination above $10 \%$ in the lowest tested osmotic potential -1.0 MPa (Figure 1), demonstrating that this weed species has a greater capacity for adaptation and competition than other species, even under salinized soil conditions. The highest averages of air and root length were obtained in the control treatment for both evaluated salts. As the $\mathrm{NaCl}$ and $\mathrm{CaCl}_{2}$ concentrations in the solution increased, these variables decreased linearly, showing a reduction close to $60 \%$ from the $-0.6 \mathrm{MPa}$ potential (Figures 3 and 4 ).

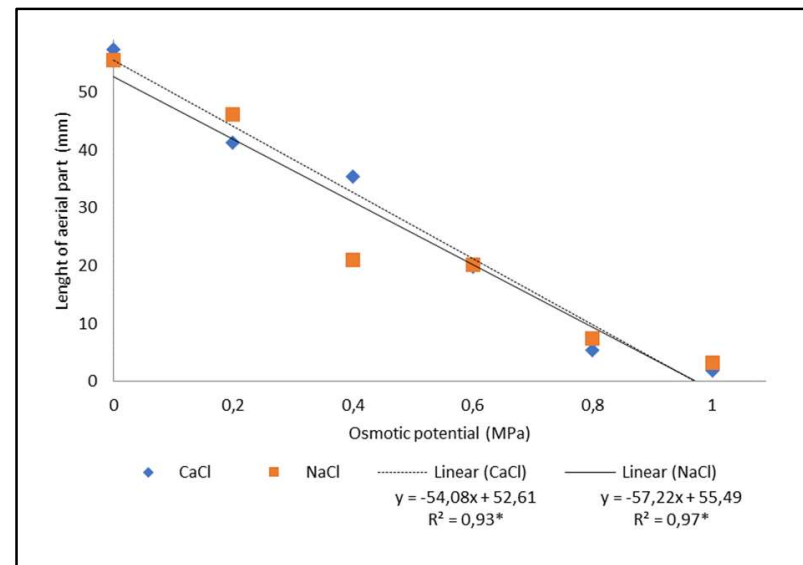

Figure 3: Length of aerial part ( $\mathrm{mm}$ ) of Macroptilium lathyroides seedlings submitted to osmotic potentials caused by salts

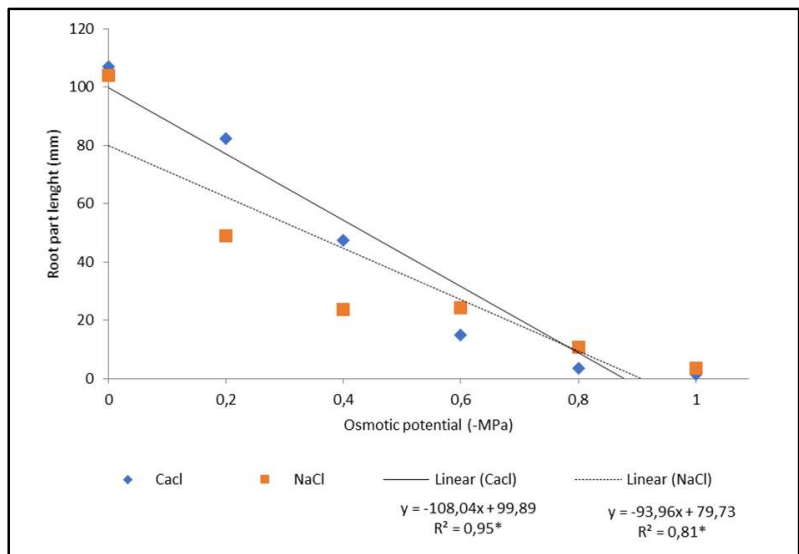

Figure 4: Root part length $(\mathrm{mm})$ of Macroptilium lathyroides seedlings submitted to osmotic potentials caused by salts.

The excess of salts in the substrate reduces the water potential of the soil and in turn restricts the absorption of water in the root environment (CARVALHO et al., 2011). These reductions in water potential, associated with the toxic effects of salts, initially interfere in the process of water absorption by seeds, which influences germination, the vigor of the resulting seedlings and, consequently, the normal development of plants (BEWLEY et al., 1994). Thus, the seed begins its germinative processes and, if there is not enough water for the process to occur normally, there may be an impediment to the emission of the root or even the death of the embryo, affecting the processes of cell division and elongation (MAYER et al., 1989; BRAGA et al., 2009), as was the case of M. lathyroides in the present study.

For the seedling dry mass variable, it was found that there was no difference between the studied concentrations up to the osmotic potential -0.6 MPa in the presence of $\mathrm{CaCl}_{2}$, with a difference only from $0.8 \mathrm{MPa}$. For the $\mathrm{NaCl}$ salt, differences were already observed from the $-0.6 \mathrm{MPa}$ potential, differing statistically from -0.8 and $-1.0 \mathrm{MPa}$ (Figure 5).

When comparing the two osmotic agents $\left(\mathrm{CaCl}_{2} \times \mathrm{NaCl}\right)$, it can be seen that the species under study was more tolerant to the presence of the saline agent $\mathrm{CaCl}_{2}$, with longer root length and dry weight (Figures 
4 and 5). In other words, in view of the stress situation, these seedlings may have invested the seed reserves in the root growth, in order to promote greater water uptake. As the seedlings go through situations of salt or water stress, they tend to direct their reserves towards the development of the root, which is an adaptive mechanism in the face of the adversities of the environment in which it is inserted (TAIZ et al., 2004).

The greater toxicity of the saline agent $\mathrm{NaCl}$ can be verified by measuring the seedlings that obtained less root development and, consequently, less dry weight. According to Toorchi et al. (2009), the greater expansion of the root system results in plants that are more resistant to the effects of soil water and salt stress because the leaf expansion during the period of exposure to osmotic stress occurs due to the amount of water present in the roots, providing the development of the plant.

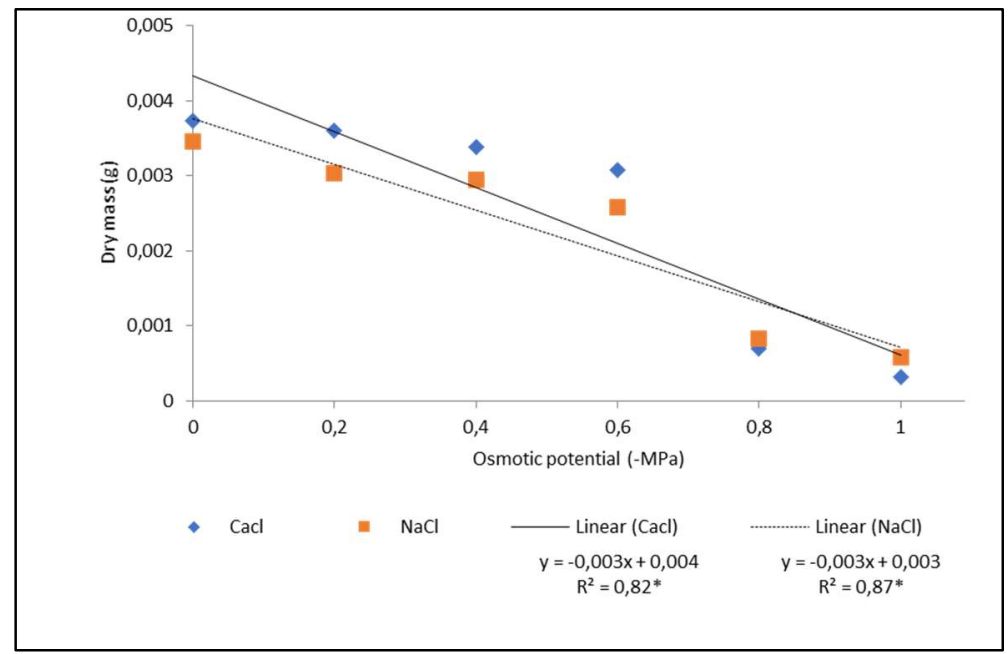

Figure 5: Dry mass of Macroptilium lathyroides seedlings submitted to osmotic potentials caused by salts.

\section{CONCLUSIONS}

The salt stress induced by the $\mathrm{NaCl}$ and $\mathrm{CaCl}_{2}$ solution causes a gradual reduction in the germination of Macroptilium lathyroides seeds, with no tolerance limit among the studied potentials. The $\mathrm{NaCl}$ salt is more critical in the root development and dry weight of the seedlings of the studied species.

AKNOWLEDGMENT: The authors would like to thank the Mato Grosso Research Foundation for the granting of a scholarship to the first author, the LaSeM/CEPTAM/Unemat team for supporting the activities necessary for the implementation and carrying out of the research and also Marcio Takeo Yamashita and Renata Yonaha Zocante for technical support for the development of research.

\section{REFERENCES}

ALMEIDA, L. D.; MAEDA, J. A.; FALIVENE, S. M. P.. Efeitos de métodos de escarificação na germinação de sementes de cinco leguminosas forrageiras. Bragantia, Campinas, v.38, n.9, p.83-96, 1979.

BRAGA, L. F.; SOUZA, M. P.; ALMEIDA, T. A.. Germinação de sementes de Enterolobium schomburgkii (Benth.)

Submetidas a estresse salino e aplicação de poliamina.

Revista Brasileira de Plantas Medicinais, Botucatu, v.11, n.1, p.63-70, 2009.
BEWLEY, J. D.; BLACK, M.. Seeds: physiology of development and germination. 2 ed. New York: Plenum Press, 1994.

CARVALHO, C. L.; KAZAMA, H. E.. Efeito da salinidade de cloreto de potássio $(\mathrm{KCl})$ na germinação de sementes e crescimento de plântulas de pepino (Cucumis sativus L.) Enciclopédia Biosfera, Goiânia, v.7, n.13, p.429-435, 2011. 
CONCENÇO, G.; ANDRES, A.; GALON, L.; PONTES, C. S.; CORREIA, V. T.. Controle de Macroptilium lathyroides com herbicidas aplicados em pré e pós-emergência. Revista Brasileira de Herbicidas, Umuarama, v.11, n.1, p.11-23, 2012.

CONCENÇO, G.; ANDRES, A.; SILVA, A. F.; GALON, L.; FERREIRA, E. A.; ASPIAZÚ, I.. Ciência das plantas daninhas: histórico, biologia, ecologia e fisiologia. In: MONQUERO, P. A. (Org.). Aspectos da biologia e manejo das plantas daninhas. São Carlos: RiMa, 2014.

FERREIRA, D. F.. Sisvar: a Guide for its Bootstrap procedures in multiple comparisons. Ciência e Agrotecnologia, Lavras, v.38, n.2, p.109-112, 2014. DOI: http://doi.org/10.1590/S1413-70542014000200001

GOMES JÚNIOR, F. G.; CHRISTOFFOLETI, P. J.. Biologia e manejo de plantas daninhas em áreas de plantio direto. Planta Daninha, Viçosa, v.26, n.4, p.789-98, 2008. DOI: http://doi.org/10.1590/S0100-83582008000400010

LARCHER, W.. Ecofisiologia vegetal. São Carlos: Rima, 2006.

LIMA, B. G.; TORRES, S. B.. Estresse hídrico e salino na germinação de sementes de Zizyphus joazeiro Mart. (Rhamnaceae). Revista Caatinga, Mossoró, v.22, n.4, p.9399, 2009.

MAGUIRE, J. D. Speed of germination-aid in selection and evaluation for seedling emergence and vigour. Crop Science, Wellington, v. 2, n. 2, p. 176-177, 1962.

MARTINS, C. C.; PEREIRA, M. R. R.; MARTINS, D.; MARCHI, S. R.. Germinação de sementes de Melaleuca quinquenervia em condições de estresse hídrico e salino. Planta Daninha, Viçosa, v.29, n.1, p.1-6, 2011. DOI: http://doi.org/10.1590/S0100-83582011000100001

MEDEIROS, P. R. F.; DUARTE, S. N.; DIAS, C. T. S.. Tolerância da cultura do pepino à salinidade em ambiente protegido. Revista Brasileira de Engenharia Agrícola e Ambiental, João Pessoa, v.13, n.4, p.406-410, 2009.

MOUD, A.; MAGHSOUDI, K.. Salt stress effects on respiration and growth of germinated seeds of diferente wheat (Triticum aestivum L.) cultivars. World Journal of Agriculture Science, Washington, v.4, n.3, p.351-358, 2008.
PELEGRINI, L. L.; BORCIONI, E.; NOGUEIRA, A. C.; KOEHLER, H. S.; QUOIRIN, M. G. G.. Effect of water stress simulated with $\mathrm{NaCl}$, mannitol and PEG (6000) on the germination Erythrina falcata Benth seeds. Ciência Florestal, Santa Maria, v.23, n.2, p.511-519, 2013. DOI: http://doi.org/10.5902/198050989295

PEREIRA, M. R. R.; MARTINS, C. C.; SOUZA, G. S. F.; MARTINS, D.. Influência do estresse hídrico e salino na germinação de Urochloa decumbens e Urochloa ruziziensis. Bioscience Journal, Uberlândia, v.28, n.4, p.537-545, 2012.

PEREIRA, M. R. R.; MARTINS, C. C.; MARTINS, D.; SILVA, R. J. N.. Estresse hídrico induzido por soluções de PEG e de $\mathrm{NaCl}$ na germinação de sementes de nabiça e fedegoso. Bioscience Journal, Uberlândia, v.30, n.3, p.687-696, 2014.

TAIZ, L.; ZEIGER, E.. Fisiologia vegetal. 3 ed. Porto Alegre: Artmed, 2004

THOMAS, W. E.; BURKE, I. C.; SPEARS, J. F.; WILCUT, J. W. Influence of environmental factors on slender amaranth (Amaranthus viridis) germination. Weed Science, Madison, v.54, n.2, p.316-320, 2006. DOI: http://doi.org/10.1614/WS$05-54.2 .316$

TORRES, S. B.. Germinação e desenvolvimento de plântulas de melancia em função da salinidade. Revista Brasileira de Sementes, Brasília, v.29, n.3, p.77-82, 2007.

TOORCHI, M.; YUKAWA, K.; NOURI, M. Z.; KOMATSU, S. Proteomics approach for identifying osmotic-stress-related proteins in soybeans roots. Peptides, San Francisco, v.30, n.12, p.2108-2117, 2009. DOI: http://doi.org/10.1016/j.peptides.2009.09.006

YAMASHITA, O. M.; GUIMARÃES, S. C.. Efecto del estrés salino sobre la germinación de las semillas de Conyza canadensis y Conyza bonariensis. Bioagro, Maracaibo, v.23, n.3, p.169-174, 2011.

YAMASHITA, O. M.; GUIMARÃES, S. C.; SILVA, J. L.; CARVALHO, M. A. C.; CAMARGO, M. F.. Fatores ambientais sobre a germinação de Emilia sonchifolia. Planta Daninha, Viçosa, v.27, n.4, p.673-681, 2009. DOI: http://doi.org/10.1590/S0100-83582009000400005

A CBPC - Companhia Brasileira de Produção Científica (CNPJ: 11.221.422/0001-03) detém os direitos materiais desta publicação. Os direitos referem-se à publicação do trabalho em qualquer parte do mundo, incluindo os direitos às renovações, expansões e disseminações da contribuição, bem como outros direitos subsidiários. Todos os trabalhos publicados eletronicamente poderão posteriormente ser publicados em coletâneas impressas sob coordenação da Sustenere Publishing, da Companhia Brasileira de Produção Científica e seus parceiros autorizados. Os (as) autores (as) preservam os direitos autorais, mas não têm permissão para a publicação da contribuição em outro meio, impresso ou digital, em português ou em tradução. 